\title{
QUALITATIVE INSIGHT ON THE IMPACT OF LEADERS' COMPETENCIES TO MOSQUE PERFORMANCE
}

\author{
Azfahanee Zakaria1 \\ Faculty of Business and Management, UiTM Kedah, Malaysia. \\ (Email: azfa292@uitm.edu.my) \\ Kamaruddin Ngah ${ }^{2}$ \\ Professor, Government, UUM College of Law, Government and International Studies, \\ Universiti Utara Malaysia (UUM), Malaysia. \\ (Email: kamarudinngah@uum.edu.my)
}

Received date: $25-07-2019$

Revised date: $28-07-2019$

Accepted date: 31-07-2019

Published date: 15-09-2019

To cite this document: Zakaria, A., \& Ngah, K. (2019). Qualitative Insight on The Impact of Leaders' Competencies to Mosque Performance. International Research Journal of Shariah, Muamalat and Islam, 1(1), 01-06.

DOI: $10.35631 /$ irjsmi.11001

\begin{abstract}
Mosque plays an important role in molding and creating beautiful success ummah. In the days of Prophet Muhammad s.a.w. the mosque is known and acts as a central place for all Muslims to practice religious ritual as well as other social activities. However, in Malaysia, the mosque is now seen as a place meant for religious rituals only and the activities held does not attract many attendees. This research aims to understand what are the core competencies which will have a significant impact on mosque performance. This is seen as necessary as having leaders with the identified core competencies will uplift the mosque institution to a higher level professionally. The research adopts a qualitative method and eighteen mosque leaders representing six mosques in the state of Kedah have been selected based on the recommendation by the religious state office respectively. Data would be collected using the interview and observation method. The result of the study aims to assist Kedah State Religious to strengthen and identify the competencies needed by the mosque leaders in managing the mosque effectively.
\end{abstract}

Keywords: Mosque, Competencies, Leaders, Mosque Performance

\section{Introduction}

A mosque is an exclusive place for Muslims around the world. It is a place where not only religious rituals are performed but also a place where many other social activities are being held. In the days of Prophet Muhammad s.a.w. the mosque was a central place meant for religious ritual and worship, education, political discussion as well as social interactions. It was also mentioned by Sulaiman, M., Siraj, S. A., \& Ibrahim, S. H. M., (2006) mosque also do 
serves as a platform to share information and to transform governmental policies within the society.

\section{Mosque and The Community Today}

However as of today, some mosque is seen as inactive and only carries activities which are religious based. Therefore, this has created a challenged whereby Muslims today need to revive the masjid as a centre of the community. Due to the advancement of technology, modernization, influence from the west as well as time constraint due to work demands, it is noted that the community have definitely change and the community's lifestyle is no longer according to the Sunnah and Al Quran (Mohd Rozaini M. R., Mahazan A, M., Abdullah A. G., Muhammad Hashim, 2014 \& Solihin., 2008). The lifestyles which is currently being practice is not balanced between what is needed now and what is needed in the world hereafter which has led to high divorced rates among couples, social ills among youth and many more. The increase of social ills and issues have forced the police department to station police officers in certain schools in Kelantan (Sulong, 2017). However, in a statement by the statistic department of Bukit Aman, there was a slight decrease in crime rate among school students in year 2013 however there is an increase of 5\% increase among teenage dropouts. It was also mentioned that the manner to show revenge have now turn more brutal and aggressive which is a danger to others (Azizah H, 2017). Besides social ills, commercial crime recorded a rise of $30 \%$ from January to Mei 2018 as compared to January to Mei 2017 (Utusan Online, 2018).

This has steered to questions by the public on what has prompted such actions by those involved with the social ills and crime rates as the actions are definitely not according to Al Quran and As Sunnah. Hence, should the community do utilize the mosque as a place for education hub, social activities or a meeting place for social interactions, as well as reverting to the teaching of Al Quran and As Sunnah, social ills and many other community challenges could be reduce (Rohana. Z, 2014)

With that, the mosque needs to be a place where all members of the community are welcome, participate and contribute knowledge to each other regardless of their age, gender, ethnicity and status. Despite the effort from the mosque management in creating activities for the community of different ages, the feedback and attendees for activities are low.

According to Mohd Rozaini M. R., Mahazan A, M., Abdullah A. G., Muhammad Hashim, (2014) on of the reason on why the attendees to the mosque is low is because the mosque management system is not being treated as a professional institution (Straits Times, 2013) Should the mosque is a professional institution, mosque would practice a management system in a systematic and order to achieve the objective of a mosque. Therefore, having a team of leaders with suitable competencies would definitely be an added advantage to the mosque. Therefore, the objective of the research is to identify on what are the competencies which is very much needed for mosque leaders in fulfilling their duties as mosque leaders. Failure of which, the mosque management would have a challenging time in managing the mosque.

\section{Mosque Management in Kedah}

There are 12 districts in the state of Kedah and the total of mosque or masjid kariah is 571 . The data is off 15 May 2019 and extracted from the official website of Jabatan Kemajuan Islam Malaysia. The 12 districts are Langkawi, Kuala Muda, Kota Setar, Kubang Pasu, Pokok Sena Padang Terap, Pendang, Bandar Bharu, Sik, Baling, Kulim and Yan. 
In the state of Kedah, each mosque is being managed by two teams ie mosque's committee and the mosque officers. Mosque committee are the leaders who plan and execute all activities in mosque (E. M. Mazlan*, A.I. Che-Ani and A. Mohd Sarman, 2018). A total of seven mosque committee are responsible to plan and execute the mosque activities and management, however only three mosque committee are elected by the kariah members on their annual general meeting. In Kedah, the Imam also holds the position as a chairman to mosque committee therefore no election is needed for the position. The balance of three other committee members is being appointed by the three who have been elected earlier. The main team would consist of seven main committee member, however additional members are allowed to be elected by the mosque committee to assist with the needed task and responsibilities which seems necessary. The team usually consist of between 10 -15 members (Jaafar A, Sanep A., Mariani A. M. \& Hairunnizam W., 2007)

As for the mosque officers which are the nazir, imam, khatib, bilal, mungkim and siak are elected by the council or the State Religious Islamic Department and the mosque officers are given an allowance for the position/task (Alia J, Nurul Fadly H., Mohd Yahya M. H., Zainizam Z. \& Asnida A.H., 2013). The mosque officers are responsible to complete their assigned duties and they are not involved with any planning of mosque activities.

\section{Competencies of A Leader}

Competencies is a set of human traits which was discovered by David McClelland in 1953 and it is mentioned that a set of competencies a better indicator to predict occupational success. Competency Model is important as it identify specific behavior and actions needed for successful leaders (Elembilassery V., 2016).

McCall, (2002) in his study discovered that the core competencies which are needed by leaders are the ability to have an open mind and flexible in their thoughts as well as strategies, the need to be sensitive to cultures which he is in, the ability to manage complex issues, the ability to be resilient, resourceful, positive and active as well as having high morality and integrity towards his work and community. And according to Hogan, K. and Kaiser, R.B., (2005) and Seiler, S. \& Pfisher, A.C., (2009), in order for a leader to be effective, he or she need to have a set of skill and competencies such as the ability to be professional, the ability to be strategic, great personal, social and has the intercultural competencies.

However, core competencies would differ for different type of position nevertheless managerial competencies are significantly needed for improving performance (Bucur, 2013).

According to Chung-Herrera, B. G., Enz, C. A., \& Lankau, M. J., (2003) in any situation or organization, it is a need for senior managers to identify appropriate competencies to a specific job as this would assist the management to having a strong team in the organization as well drawing a succession plan for the team. Should the competency identified is not specified, chances that the wrong competency and criteria would be look at in a candidate which will create unnecessary job fit match. However, in a study held by Ahmad A., Silong A. D., and Abbasiyannejad M., (2015), it was noted that for leaders who lead teams at the village, leaders need to have the skills to obtained funds and resources, the skills to write and present ideas, the entrepreneurship skills, the interpersonal skills as well as the ability to delegate task. This is seen necessarily as this competency would be useful in influencing the other parties to contribute and grant funds for the projects plans. 
Engen Kae V, (2012) in her study stated that leadership depends on interaction and the use of communication. It is viewed necessary for leaders to possess the ability to listen as this will lead and allow the leaders to pay attention to the needs and feedback of the followers. The ability to response and listens to what the ideas of the followers would later create and build trust among the followers and the leader. Trust also would create a bond between the group which would later and later respond to their followers. Trust acts as a glue which binds the leader its followers as well as offers the ability for organizational and leadership success. (Mineo, 2014). Trust can be obtained should the leader practices an open and accessible communications and also applies integrity in carrying out its objective and goal with consistency. Besides that, leaders also need to show appreciation and allow for collaboration with followers in certain decision-making process. Leaders also need to demonstration fairness among the team which comprises secure treatment in terms of rewards and absence of favouritism work matters.

Soft skill is also an essential competency which leaders need to have who. Having the ability to concur soft skill, leaders would be able to communicate verbally and non-verbally to gain trust and confidence. Having the soft skill ability will assist in solving problems as a social process with consensus rather than giving and instructing for correct answers.

Another major human skill needed in order to survived in the 21 st Century are the skills to learn and innovate, the skills to solve problems, the ability to communicate and cooperate. The ability to think creatively and the ability to think critically. It was also mentioned that having the skills to deal and communicate with information technology is a skill needed as well (Wijan, 2012).

\section{Methodology}

This study implements a qualitative research method whereby eighteen mosque officers from six mosques will be interviewed. Qualitative research is done with the intention to understand the social reality of individuals, groups and cultures (Denzin \& Lincoln 2004). The researcher would also observe and participate in the activities held at the mosque in order to further observe and understand the issue which may arise in the mosque management. The mosque officers would represent both mosque which have been awarded with Best Mosque Award and also mosque which have been identified as not very active recommended and identified by the officers from the Islamic Religious Office of the district. 


\section{Conceptual Framework}

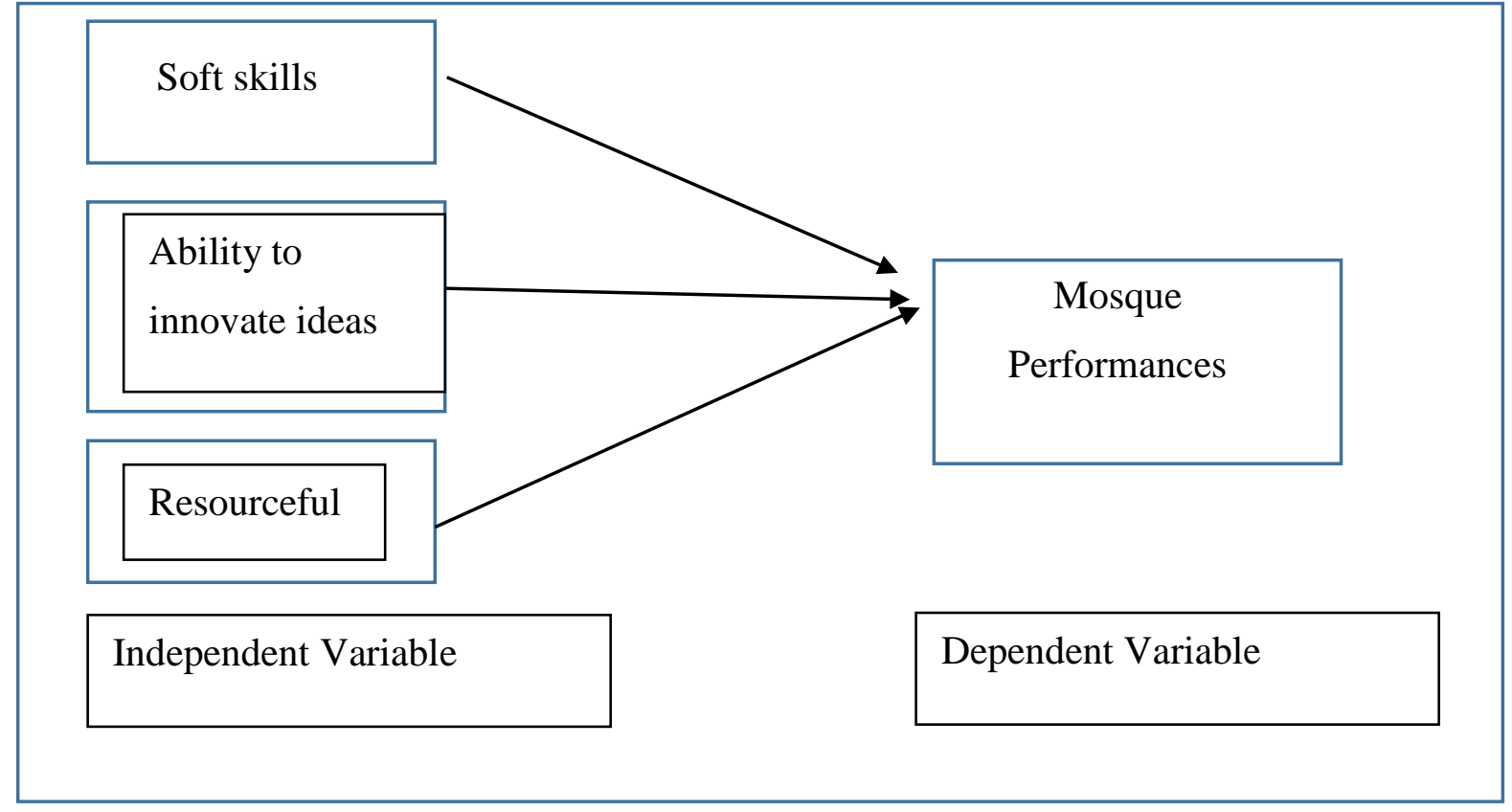

Figure 1.1: Conceptual Framework

The conceptual framework above shows the independent variable which are soft skills, the ability to innovate ideas and the competency of being resourceful which would be studied in this research. The three competencies are seen to have an impact on the ability of the mosque leaders in ensuring that the mosque performances are being met.

\section{Conclusion}

The findings of the study aim to assist Kedah State Religious to strengthen and identify the competencies needed for mosque leaders as they are the leaders who would plan and execute the mosque activities. Through the activities, may it be religious or social activities organized would assist in the improvement of knowledge as well as socio economy for the community. However, this would not be achieved should the numbers of attendees in the activities are low and the attendees to the daily five-time prayers are low. Therefore, by identifying the competencies, mosque leaders would be able to manage the mosque more effectively and this would

\section{References}

Ahmad A., SIlong A. D., and Abbasiyannejad M., (2015). Competencies of Effective Village Leadership in Malaysia. J. Asian Dev Stud, 4(2).

Alia J, Nurul Fadly H., Mohd Yahya M. H., Zainizam Z. \& Asnida A.H. (2013). A Proposed Model For Startegic Management (SM) and Mosque Performance (MP) in Mosque Management. International Journal of management Information Technology and Engineering, 1, 29-36.

Azizah H. (24 September, 2017). Adakah Belia Semakin Ganas?

Azlan A. R. \& Rashidi A.,. (2017). PERSEPSI MASYARAKAT TERHADAP PROGRAM PENGIMARAHAN MASJID DI. 4th International Conference on Masjid, Zakat and Waqf Management 2017 (IMAF-2017). Selangor.

Bucur, I. (2013). Managerial Core Competencies as Predictors of MAnagerial Performance, on Different Level of Management. Procedia Social and Behaviorol Science, 365-369. 
Chung-Herrera, B. G., Enz, C. A., \& Lankau, M. J. (2003). Grooming future hospitality leaders: A competencies model. Cornell Hotel and Restaurant Administration Quarterly, 3.

Denzin, N. (1978). The logic of naturalistic inquiry. IN Denzin, N.K (ed) Sociology methods: A sourcebook. New York: Mc Graw Hill.

E. M. Mazlan*, A.I. Che-Ani and A. Mohd Sarman. (2018). Management Of Building Mosque In Malaysia. World Journal of Engineering Research and Technology, 48-56.

Elembilassery V. (2016). Competency Framework for Non- Profut Organizations: An exploratory Study Basaed on Indian Organizations. International Journal of Human Resource Studies, 6(2), 272-284.

Jaafar A, Sanep A., Mariani A. M. \& Hairunnizam W. (2007). Dana dan Harta Masjid di Malaysia: ke Arah Pengurusan Strategik.

Mohd Rozaini M. R., Mahazan A, M., Abdullah A. G., Muhammad Hashim. (2014). Kepimpinan, Prestasi MAsjid Dan Pembangunan Komuniti Menurut Al-Quran dan Hadith. Proceeding of the International Cnference on MAsjid, Zakat adn Waqf (IMAF 2014), (pp. 16-25).

Mineo, D. L. (2014). The Importance of Trust in Leadership. Research Management Review, 20(1).

Rohana. Z, Z. F. (2014). IMPLIKASI TADABBUR AL-QURAN DALAM PEMBENTUKAN INSAN YANG. International Conference on Postgraduate Research. Kuala Lumpur. doi:e-ISBN 978-

Sulaiman, M., Siraj, S. A., \& Ibrahim, S. H. M.. (2006). Internal Control Systems in West Malaysia's State. The American Journal of Islamic Social Sciences, 25(1), 63 - 80.

Solihin., S. M. (2008). Islamic Da'wah: Theory and Practice. IIUM Press International Islamic Unniversity Malaysia.

Wijan, P. (2012). How to develop learning for the 21stCentury Students. Bangkok. Sodsrisaridwong Foundation. 